\title{
Harnessing the Economic and Environmental Benefits of Bamboo in Nigeria
}

\author{
Nijerya'da Bambunun Ekonomik ve Çevresel Faydalarını Kullanmak
}

\author{
Asiru Monday ABBAS \\ Department of Agricultural Economics and Rural Sociology, Ahmadu Bello University, Zaria, Kaduna State \\ (asiruabbas@gmail.com) \\ Unekwu Hadiza AMANABO \\ National Space Research and Development Agency, Abuja, Federal Capital Territory (uneks55@gmail.com)
}

Keywords:
Bamboo
Environmental
Importance
Economic Benefits
Utilization
Industry

Anahtar
kelimeler:
Bambu
Çevresel Önem
Ekonomik Fayda
Yarar
Endüstri

\begin{abstract}
The study painstakingly examined how Nigeria can tap into the economic and environmental benefits of bamboo. The study further looked at the wide range uses of bamboo in many fields such as textile industry, furniture industry, paper industry, weaving industry and its role in the environment as a carbon sink. As a multi-purpose plant and also due to its fibrous root and gregarious growth pattern, bamboo has the ability to control soil erosion. The study opined that as useful as bamboo is in so many fields, there can't be much progress if there is no substantial capital investment in research, cultivation and utilization. It is recommended that there should be more awareness on the various uses of bamboo especially in the production of toothpick which Nigeria imports and its role in mitigating the issue of global warming as a result of its ability to carry out carbon sequestration.
\end{abstract}

\section{ÖZET}

Çalışma, Nijerya'nın bambu maddesinin ekonomik ve çevresel faydalarına etkilerini incelemektedir. Çalışma ayrıca tekstil endüstrisi, mobilya endüstrisi, kağıt endüstrisi, dokuma endüstrisi ve çevreye karbon lavabo olarak rolü gibi pek çok alanda bambu ürününün geniş kullanım alanlarını ortaya koymaktadır. Çok amaçlı bir bitki olarak ve ayrica lifli kök ve toplu gelişme modelinden dolayl, bambu toprak erozyonunu kontrol etme kabiliyetine sahiptir. Çalışma, bambunun bir çok alanda yararlı olduğunu, ancak araştırma, geliştirme ve kullanımda önemli bir yatırım yapılmadığı takdirde çok fazla ilerleme kaydedilmeyeceğini ifade etmektedir. Çalışmada sonuç olarak, Bambu'nun çeşitli kullanımları konusunda daha fazla farkındalık yaratılması önerilmektedir.

\section{INTRODUCTION}

Bamboo is a drought tolerant, evergreen, perennial woody plant that belongs to the grass family, Poaceae. Bamboo is an important Non Timber Forest Product (NTFP) which occurs in a wide variety of climatic and edaphic conditions and it is one of the fastest growing plant species in the world which can be raised easily, quickly and substantially harvested in three to five years cycle (Mishra, 2015). Bamboo is naturally distributed in the tropical and subtropical belts between approximately $46^{\circ}$ north and $47^{\circ}$ south latitude, and is commonly found in Africa, Asia, Central and South America (Food and Agriculture Organization, 2007). Dwarf bamboo species grow to only a few centimetres $(\mathrm{cm})$, while medium-sized bamboo species may reach a few metres $(\mathrm{m})$ and giant bamboo species grow to about $30 \mathrm{~m}$, with a diameter of up to $30 \mathrm{~cm}$ (FAO, 2007). According to Ffan (2003), some of the species of bamboo that have been identified in Nigeria include Bambusa vulgaris and Oxytenanthera abyssinica; the former attains a height of between $14-20$ metres at maturity with a girth of about $20 \mathrm{~cm}$ while the later reaches between $8-12$ metres at maturity. In Nigeria, Bamboo is found in a number of 
states particularly in the southern part of the country. According to a report by Raw Materials Research and Development Council (2004), the most endowed states in terms of bamboo occurrence are observed to be Ogun, Oyo, Osun, Ondo, Edo, Delta, Rivers, Akwa Ibom, Cross River, Abia, Ebonyi, Enugu, Anambra and Imo States and at least 10\% of the natural vegetation in these states is dominated by bamboo, with existing bamboo clumps showing appreciable gregarious growth that is contiguous over large areas. The report also indicated pockets of bamboo clumps in Niger, Taraba and Plateau States as well as within the Federal Capital Territory. Figure 1 according to FAO (2007), shows the level of bamboo occurrence in Nigeria.

Bamboo has attracted significant attention over the last two decades as a result of its environmental, economic and aesthetic values. In Africa, Asia and Latin America, it is closely associated with indigenous culture and knowledge and is widely used for housing, forestry, agroforestry, agricultural activities and utensils (FAO, 2007). The unique properties of bamboo make it a special economic resource for a variety of uses and poverty alleviation. It grows rapidly and can be harvested on yearly basis without damaging the soil where it grows. Bamboo can grow on marginal land, not suitable for agriculture or forestry, or as an agroforestry crop and it has a relatively light weight because the culms are hollow, and unlike wood, it can be easily harvested and transported without specialized equipment or vehicles (FAO, 2007). Bamboo processing into crafts is done by local people especially by those in the lowest stratum of the society to generate income which they use for household spending.

The economic importance of bamboo in the provision of employment, income generation, poverty alleviation and so on cannot be over-emphasized. A lot of rural dwellers make ends meet by making handicrafts from bamboo. In rural areas, bamboo is extensively used in making fence, planted around ponds as water shed to reduce evaporation, making of wooden gong, used as stakes for yams, decking of upstairs buildings, supporting lodging banana and plantain, building thatched houses (Nwaihu et al., 2015).

Environmentally, the biological characteristics of bamboo make it a perfect tool for reducing carbon dioxide levels in the atmosphere and it generates more oxygen than equivalent strands of trees, lowers light intensity, protects against ultraviolet rays and is an atmospheric and soil purifier (Mishra, 2015). Burgeoning human population is putting enormous pressure on resources globally and this has resulted in environmental degradation, climate change, depletion of land and water resources, health hazards; and something urgent has to be done to remedy the situation. A lot of forests in Nigeria has been degraded as a result of activities such as logging, industrialization, urbanization and in the process a lot of valuable trees were cut down without being replaced. Considering the environmentally benign nature of bamboo, its wide range of uses and the income it generates for processors, especially for rural people who sell a lot of handicrafts which they make from it; this study carefully looks at how Nigeria can tap into the economic and environmental benefits of bamboo. 


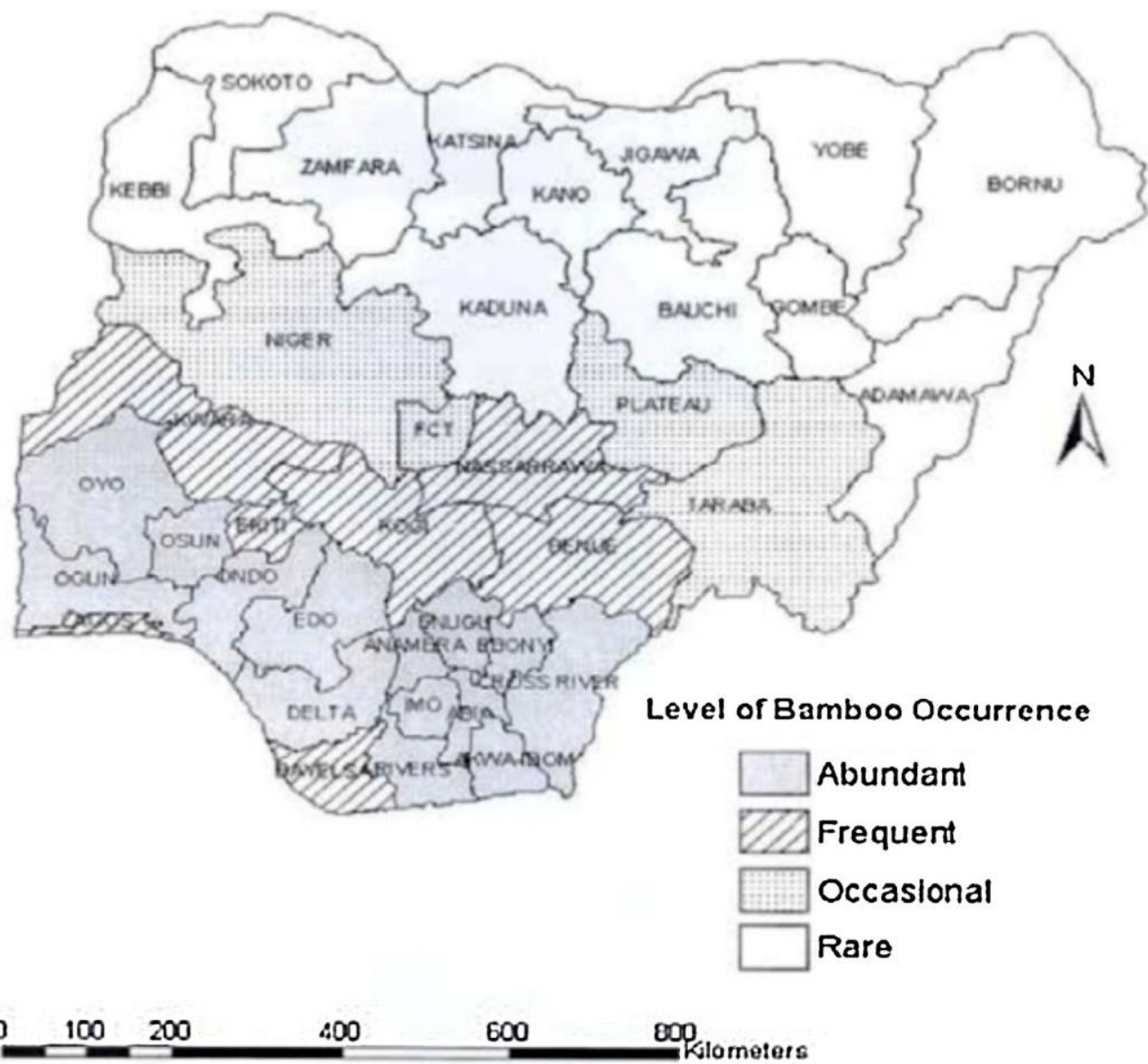

Figure 1: Map of Nigeria showing the level of bamboo occurrence

Source: FAO, 2007

\section{ECONOMIC IMPORTANCE of BAMBOO}

Bamboo as a 'wonder plant' has a wide range of economic uses that if fully tapped into in a country like Nigeria, it will not only help in alleviating poverty locally but will also serve as a foreign exchange earnings for the country. Some of the economic importance of bamboo in different areas are listed below:

\subsection{Textile Industry}

Bamboo is a renewable natural resource that is available and widely distributed in a number of states in Nigeria. According to Ogunwusi (2013), bamboo is a good clothing material as a result of its hollow fibre that is filled with micro gaps and micro holes, which allow for better moisture absorption and ventilation than other fibres. Ogunwusi (2013) also reported that bamboo fabric is thermal regulating, naturally hypoallergenic, anti-bacterial in nature, comfortable to wear, wrinkle resistant and has a superior wicking capability. According to Munjal and Kashyap (2013), bamboo apparels include sweaters, bath suits, blankets, towels; and these apparels have a distinctive light texture and are also soft and cool. Nigeria's import bill on cloth importation from western and eastern countries annually is staggering. This is totally unacceptable in a country with raw material like bamboo that can be deployed in the production of cloths to meet local demand and also for export. If the United States of America and Chinese governments are making millions of dollar from bamboo textile, 
Nigeria can also make much more money if resources are devoted in the areas of research, production and utilization of bamboo.

There are two main methods used in obtaining clothing material or textile from bamboo and these methods are chemical and mechanical process. Waite (2009) reported that the chemical process for producing regenerated bamboo fibre using hydrolysis alkalization and multi-phase bleaching technology consists of series of stages which are listed below:

1. Leaves and inner fibre are removed from bamboo.

2. Leaves (in some cases) and inner fibers are crushed together to make bamboo cellulose.

3. Bamboo cellulose is soaked in a solution of $18 \%$ sodium hydroxide $(\mathrm{NaOH})$ at $20-25^{\circ} \mathrm{C}$ for 1 to 3 hours.

4. Bamboo cellulose and $\mathrm{NaOH}$ mixture is pressed to remove excess $\mathrm{NaOH}$, crushed by a grinder, and left to dry for 24 hours.

5. Carbon disulfide, $(\mathrm{CS} 2)$, is added to the mixture.

6. Bamboo cellulose, $\mathrm{NaOH}$ and $\mathrm{CS} 2$ mixture is decompressed to remove excess CS2, resulting in cellulose sodium xanthogenate.

7. A diluted solution of $\mathrm{NaOH}$ is added to the cellulose sodium xanthogenate, which dissolves it into a viscose solution.

8. The viscose is forced through spinneret nozzles into a large container of a dilute sulfuric acid solution, (H2SO4) that hardens the viscose and reconverts it to cellulose bamboo fibre.

9. The bamboo fibres are spun into yarns (to be woven or knitted).

In the mechanical process as reported by Ogunwusi (2013), the woody parts of the bamboo plant are crushed and natural enzymes are used to break the bamboo walls so that the fibres can be mechanically combed out and spun into yarn; the bamboo fibre product made from this process is sometimes called bamboo linen and this manufacturing process is ecofriendly. Figure 2 according to Schroder (2016) depicts a bath towel made from bamboo. 


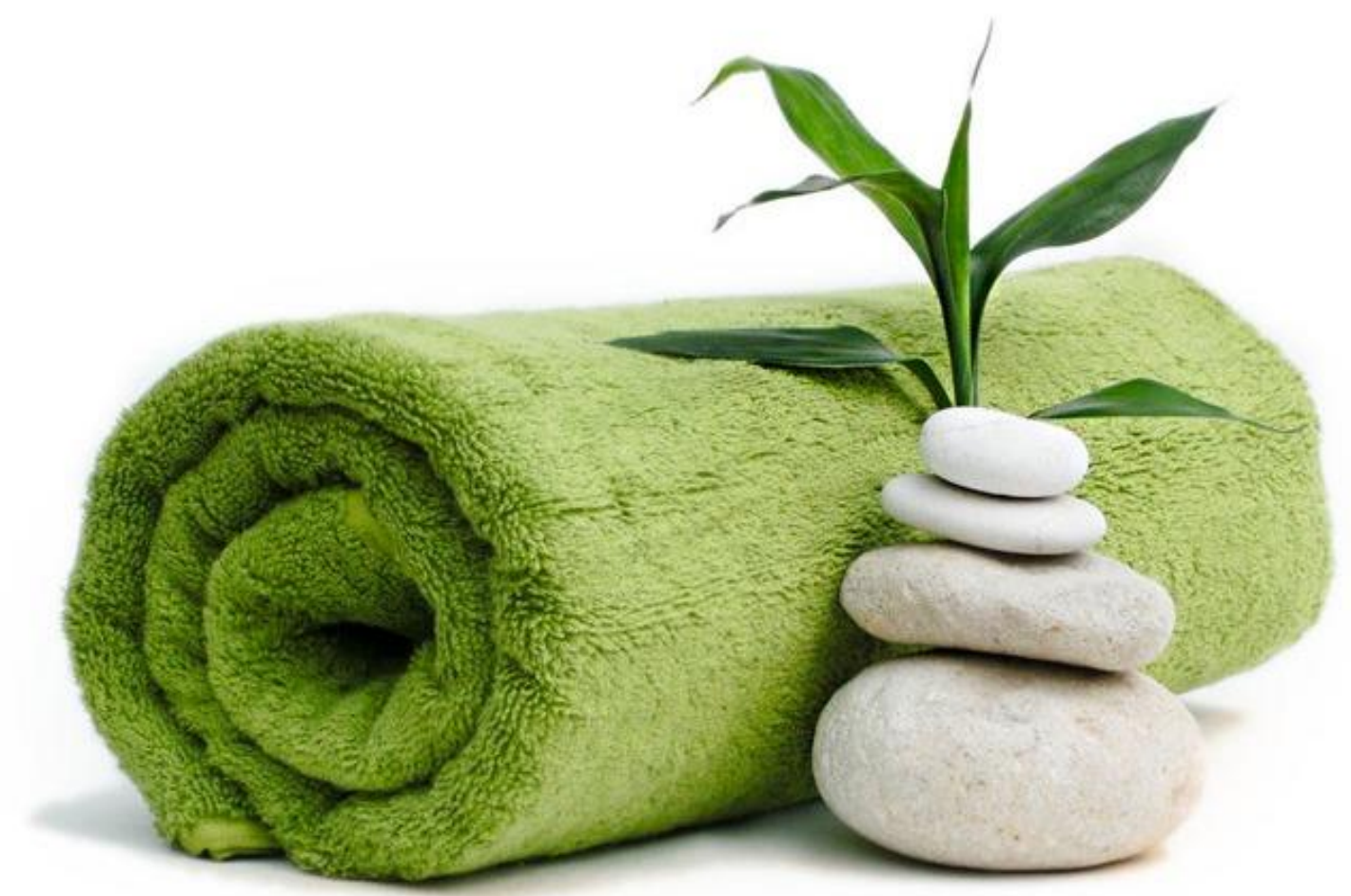

\section{Figure 2: Bamboo bath towel}

\section{Source: Schroder, 2016}

\subsection{Paper Industry}

Bamboo is used as a raw material in paper industry to manufacture tissue paper, A4 paper, cardboard etc. Bamboo paper has practically the same quality as paper made from wood and its brightness and optical properties remain stable, while those of paper made from wood may deteriorate over time (FAO, 2007).

\subsection{Toothpick Production}

It is outrageous to hear that a country like Nigeria spends so much money annually on the importation of toothpicks from some Asian countries when bamboos that are used in the production of toothpick are available in large quantity in the country. All that is needed is investment in the right infrastructure to ensure that the country is not only self-sufficient in toothpick production but also able to export to other countries of the world particularly on the continent of Africa. In a country like Nigeria where there is high level of youth unemployment with its attendant consequences such as terrorism, kidnapping, militancy, robbery, the country can tap massively into the use of bamboo in the production of toothpick to ensure that the teeming unemployed youths are productively engaged. If the idle youths are gainfully employed, the government will spend less money on fighting criminal activities in the society. The toothpick business is a big industry that if fully tapped into will go a long way in reducing the level of unemployment and youth unrest in the country. 


\subsection{Weaving Industry}

Bamboo handicrafts generate a lot of income for rural dwellers that their livelihoods depend on it. Bamboo is woven into different products such as mats, baskets etc. Some of these crafts are displayed in homes and hotels for decoration because of their aesthetic value.

\subsection{Charcoal Production}

Nigeria is a country where wood charcoal is very common and it is a known fact that the production of wood charcoal leads to deforestation which Nigeria is trying to curtail. Bamboo charcoal can be used as a substitute for wood charcoal. Bamboo grows rapidly and its wide availability particularly in the southern part of the country makes it a cheap raw material for charcoal production. Using bamboo to make charcoal will ensure that our forests are not over-exploited as a result of wood charcoal production. According to Schroder (2016), bamboo charcoal and other products made from bamboo are shown in figure 3 .

\subsection{Furniture Industry}

Bamboo is a valuable raw material in making different types of furniture such as tables, upholstery chairs, bed etc. The furniture industry is a multi-million Naira industry that employs a lot of people. With bamboo as a cheap raw material and also with appropriate technology, more people will be employed in the furniture industry. During the last 15-20 years, bamboo has developed as an exceptionally valuable and often superior substitute for wood and bamboo-based panels and boards are hard and durable and may successfully substitute for hardwood products (FAO,2007).
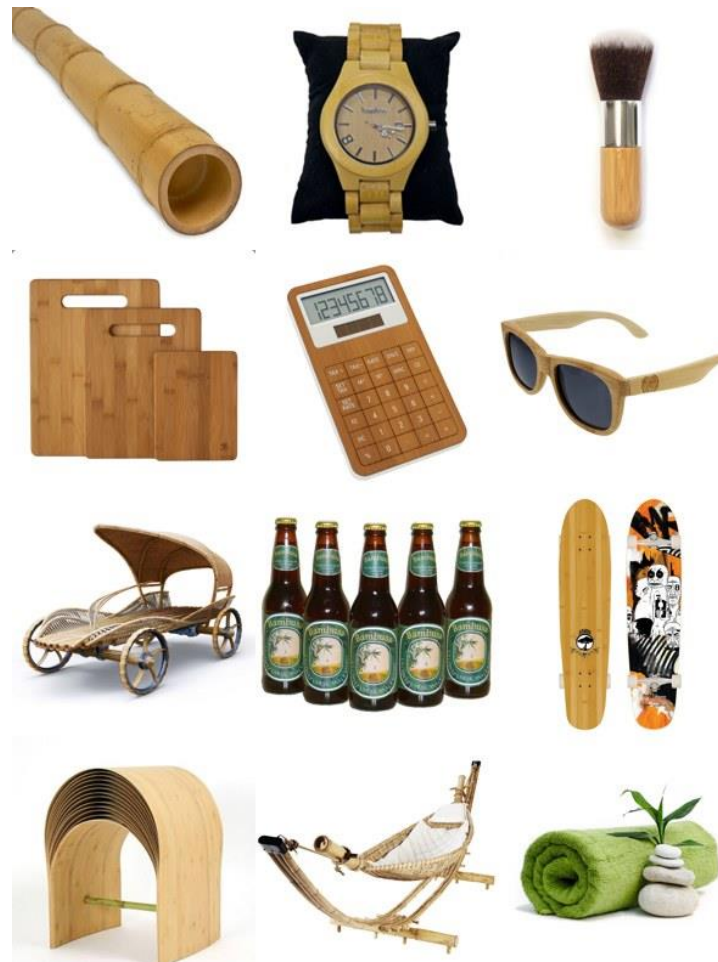
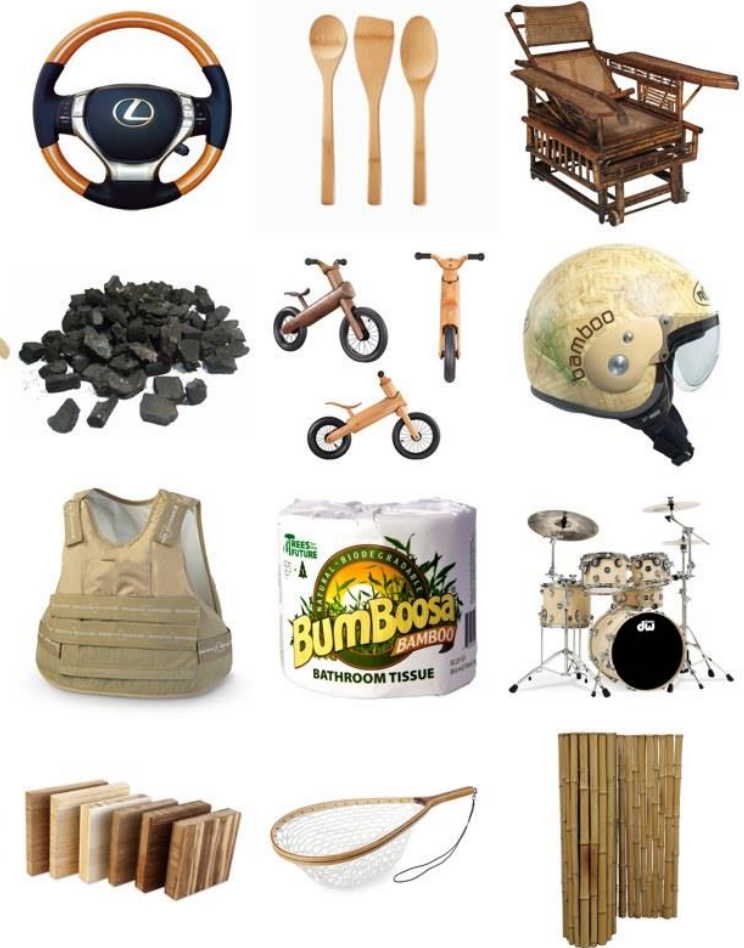

Figure 3: Bamboo products

Source: Schroder, 2016 


\section{ENVIRONMENTAL BENEFITS of BAMBOO}

Bamboo is an evergreen plant that grows rapidly and gregariously. It has a fibrous root system that enables it to hold the soil particles together. Bamboo also has the capacity to produce leafy mulch which helps to increase the organic matter content of the soil and this mulch has a way of retaining water during rainfall which keeps the soil surface cool, thereby reducing the rate at which water is lost from the soil surface. Some of the environmental importance of bamboo are listed below:

\subsection{Reduction in Deforestation Rate}

The increasing rate of deforestation as a result of logging and other activities (road construction, industrialization and urbanization) make the search for an eco-friendly alternative pertinent. As a result of its wide range of uses in the furniture industry, bamboo serves as a substitute for timber, thereby, reducing the rate at which forest is being depleted. Cutting down of trees for the purpose of using them as timber is a major activity particularly in the southern part of Nigeria and this has impacted negatively on the ecosystem, resulting in the loss of biodiversity and with other dire consequences for the environment. When trees are chopped down, it takes years to replace them unlike bamboo which grows rapidly and can be harvested within a few years. Commercially important species of bamboo usually mature in four to five years (versus 10 to 25 years for most soft woods) (Mishra, 2015). Bamboo may replace wood in many industrial applications and thereby contribute to the saving and restoration of the world's forests (FAO, 2007).

\subsection{Erosion Control}

Globally, erosion poses a serious threat to the environment and result-oriented agricultural practice. Erosion has damaged much of the land in eastern parts of Nigeria and this has resulted in land degradation and environmental hazard. According to Jimoh et al. (2012), for instance, active and inactive gullied surface areas range from 0.7kilometres for Ohafia and 1.15kilometres for Abiriba in Abia State. The width of the gulley ranges from 0.4kilometres for Ohafia and 2.4kilometres for Abiriba. Bamboo roots hold the soil particles together thereby preventing them from being washed away by erosion. The sum of stem flow rate and canopy intercept of bamboo is $25 \%$ which means that bamboos greatly reduce rain run-off and also help to control landslides, keep flooded rivers along their natural course and slow the speed of water flow (Mishra, 2015). In Brazil, bamboo species like Bambusa blumeana and Phyllostachys pubescens were introduced to check soil erosion, prevent nutrient loss and improve soil structure (Fu et al., 2000). The valuable features of bamboo for controlling soil erosion are its extensive fibrous root system, connected rhizome system, the leafy mulch it produces on the soil surface, its comparatively dense foliage which protects against beating rains, and its habit of producing new culms from underground rhizomes which allows harvesting without disturbing the soil (Zhou et al., 2005). Bamboo grows on degraded soil and does not necessarily require fertilizer application. Therefore, bamboo will serve as a useful plant to check erosion in areas that have been affected by erosion in Nigeria particularly in the south eastern part of the country.

\subsection{Carbon sequestration}

Bamboo as a multi-purpose plant, also, has the ability to carry out carbon sequestration. In plantations, where annual harvesting of culms is selectively done, bamboo can sequester more carbon, especially if the harvested carbon are turned into durable products according to Karmakar and Haque (2008). Extreme growth of bamboo minimize carbon dioxide and generates up to 35\% more oxygen than equivalent stands of trees (Munjal and Kashyap, 2013). This implies that bamboo helps in mitigating the issue of greenhouse effect and global warming. Therefore, bamboo serves as a carbon sink in as much there is more of it and over-exploitation of bamboo resource base is also avoided. 


\section{CONSTRAINTS TO BAMBOO UTILIZATION in NIGERIA}

\subsection{Policy issue}

Bamboo does not feature prominently among the crops on the priority list of the Nigerian Government. Unless there is a clear-cut policy on bamboo, Nigeria may not benefit much from its variety of uses. In Nigeria, bamboo is not reckoned with by policy makers and development professionals even though it has huge economic and environmental benefits.

\subsection{Inadequate modern technology for bamboo processing}

The agricultural sector in Nigeria is plagued by inadequate modern technology and bamboo is no exception. Appropriate technology to transform bamboo into different finished products is either lacking or insufficient. Bamboo has a wide range of uses in a lot of sectors such as textile industry, furniture industry, automotive industry, crafts making; but if the appropriate technology to transform bamboo into finished products is not available, its utilization will only remain a dream.

\subsection{Insufficient information on bamboo uses}

There is no adequate information on bamboo uses in Nigeria. Apart from the residual knowledge of using bamboo as yam stakes, scaffolds, for fencing; most people do not know that there are a lot of other things that bamboo can be used for. Even in the academia, only few researchers delve into research on bamboo; attention is focused more on crops such as rice, maize, beans, yam, cassava etc. As a matter of fact, not much information is available on bamboo utilization in Nigeria.

\section{CONCLUSION}

It cannot be over-emphasized that bamboo is an eco-friendly plant that has many uses and Nigeria as a country must tap into it and use it to create employment for her teeming youths, majority of whom are unemployed. Bamboo is a renewable natural resource with both economic and environmental benefits. For any appreciable progress to be made, we must look beyond the traditional uses of bamboo as scaffolds, yam stakes, fence, construction materials for thatched houses etc. As a country that wants to diversify her economy, Nigerian government must invest massively in research on cultivation and utilization of bamboo; also cottage industries that are transforming bamboo into different products must be supported with grants that must be properly monitored in order to ensure that the funds are not diverted to other uses. In order to ensure sustainable development in the bamboo sector, there must be reliable data on bamboo resources, management and uses in Nigeria.

\section{REFERENCES}

FFAN, O.O. (2003). Bamboo and Rattan: vehicle for poverty alleviation in Nigeria. A paper submitted to the XII World Forestry Congress, 2003, Quebec City, Canada.

Food and Agriculture Organization. (2007). Non-Wood Forest Products 18. World Bamboo Resources: a thematic study prepared in the framework of the Global Forest Resources Assessment 2005, Rome, Italy.

FU, M., XIAO, J. and LOU, Y. (2000). Cultivation and utilization of bamboo. Forestry Publishing House, Beijing, China.

JIMOH, H.I., AJEWOLE, O.D., ONOTU, S.I. and IBRAHIM R.O. (2012). Implications of land degradation, reclamation and utilizations in the oil producing areas of Nigeria: perspectives on environmental sustainability and development. Environmental Research Journal, 6(2): 100-105.

KARMAKAR, K. and HAQUE, M. (2008). Proceedings of the International conference on improvement of bamboo productivity and marketing for sustainable livelihood, 15th - 17th April 2008, pp.113-128, New Delhi, India.

MISHRA, V. (2015). Bamboo and its connectivity to different fields of economics: a potential resource of modern India. International Journal of Innovative Research and Development, 4(2): 140-145. 
MUNJAL, K. and KASHYAP, R. (2013). Bamboo Fibre: an approach toward sustainable development. International Journal of Science and Research, 4(4): 1080-1083.

NWAIHU, E.C., EGBUCHE, C.T., ONUOHA, G.N., IBE, A.E., UMEOJIAKOR, A.O. and CHUKWU, A.O. (2015). Socio-economic importance and livelihood utilization of bamboo (Bambusa vulgaris) in Imo State, Southeast Nigeria. Agriculture, Forestry and Fisheries, 4(3-1): 81-85.

OGUNWUSI, A.A. (2013). Bamboo: an alternative raw material for textiles production in Nigeria. Chemistry and Materials Research Journal, 3(11): 6-18.

Raw Materials Research and Development Council. (2004). Bamboo Production and Utilization in Nigeria, RMRDC, Abuja, Nigeria.

SCHRODER, S. 1000 products made from bamboo. (2016). https://www.bambooimport.com/en/blog/products-made-frombamboo, (Accessed 25.04.2017).

WAITE, M. (2009). Sustainable textiles: the role of bamboo and the comparison of bamboo textile properties, Journal of Textile and Apparel Technology and Management, 6(2): 1-21.

ZHOU, B., FU, M., XIE, J., YANG, X. and LI, Z. (2005). Ecological functions of bamboo forest: research and application, Journal of Forestry Research, 16(2): 143-147. 